\title{
Effect of different extraction methods on fiber quality of nettle (Urtica dioica L.)
}

\author{
Laura Bacci', Sara Di Lonardo', Lorenzo Albanese', \\ Giorgio Mastromei ${ }^{2}$ and Brunella Perito ${ }^{2}$
}

Textile Research Journa 8I(8) 827-837

\begin{abstract}
Chemical extraction, water retting, microbiological and enzymatic methods were applied on entire nettle stalks and/or unretted decorticated fiber of a selected fiber nettle clone. Morphological and mechanical properties and chemical composition were then determined on fiber samples.

The first interesting result concerned the good degree of separation between fibers and shives obtained by mechanical scutching applied on stalks stored for I year, probably resulting from natural retting processes occurring during the storage.

Microbiological retting (anaerobic plus aerobic bacteria) of entire stalks and/or unretted decorticated fiber produced fibers with a higher quality than water retting.

Both enzymes used (Viscozyme ${ }^{\circledR} L$ and Pectinex ${ }^{\circledR}$ Ultra SP-L), improved fiber quality if EDTA was added. The enzyme vat retting gave good results on both water-retted fibers and unretted decorticated fibers, while the spray enzyme treated fibers usually displayed thicker diameter, lower cellulose content and, for Viscozyme ${ }^{\circledR}$ L, lower strength values, without differences between the two storage methods used after enzyme application.
\end{abstract}

\section{Keywords}

Fiber nettle, fiber characteristics, retting methods, textile

\section{Introduction}

Natural fibers have gained renewed interest over the last decade due to their varied uses in textiles, composites, handicrafts, packaging, etc., and consumer demand for environmentally sustainable and traceable processing chains.

Fiber nettle (Urtica dioica L.) was cultivated in central Europe during the $19^{\text {th }}$ century until the Second World War and has a long history as a fiber plant in Germany and Austria, ${ }^{1}$ where it was used for textiles, similarly to flax (Linum usitatissimum L.) and hemp (Cannabis sativa L.), prior to the introduction of cotton (Gossypium sp.). In recent years it has been reintroduced in Germany and The Netherlands, confirming the evidence that the use of nettle for a sustainable and local fiber-producing industry, with low environmental impact, could be economically promising.

Indeed, nettle crop requires low agronomic inputs so is highly feasible for organic farming, as a perennial crop it reduces soil erosion and being a nitrophilous species it recovers over-fertilized soils.
Fiber nettle has also recently been studied to evaluate its potential production in Tuscany (Italy) in order to produce and process it locally, ${ }^{2}$ not only for textile purposes but also for its utilization in cosmetics and medicine, ${ }^{3}$ in accordance with the multifunctional concept of crop species. That, among other things, would allow the sharing of cultivation costs among different production sectors.

Retting is the major problem in extracting natural fibers. ${ }^{4}$ In this process, bast fiber bundles are separated

\footnotetext{
'Institute of Biometeorology (IBIMET), National Research Council (CNR), Italy.

${ }^{2}$ Department of Evolutionary Biology 'Leo Pardi', University of Florence, Italy.

Corresponding author:

L. Bacci, Institute of Biometeorology (IBIMET), National Research Council (CNR), Via Giovanni Caproni 8, 50145 Florence, Italy Email: I.bacci@ibimet.cnr.it
} 
from the core by pectin and hemicellulose disintegration. ${ }^{5}$

Two different methods (dew retting and water retting) are traditionally used to process bast fibers, both carried out by indigenous microorganisms. In dew retting, stems are strewn in the field where they are attacked by pectinolytic enzymes secreted mainly by fungi. ${ }^{6}$ In water retting, stalks are put in tanks filled with well-water where a pectinolytic community develops. ${ }^{7}$ Water retting produces better quality fibers, but the stench from fermentation by anaerobic bacteria, the resulting stench-tainted fibers and high labor costs prevent water retting from being widely used today. The use of pure bacterial cultures could ret fibers to a higher yield and quality than natural microflora, as already found for flax by Donaghy et al. ${ }^{8}$

Dew retting, despite being widely applied due to its cheapness, suffers from many drawbacks because of dependence on the weather, large variation in fiber quality and the uncontrollability of the process with a consequent risk of fiber damage. ${ }^{69}$ Improvements based on new methodologies are therefore needed to produce constantly high quality fibers. ${ }^{5}$ Gillespie et al. ${ }^{10}$ suggested that enzymatic retting may be faster and more reproducible than traditional methods and may provide spinners with fibers of higher and more uniform quality. Most studies aiming to set up new fiber extraction methods have concerned flax and there is a wide range of literature describing the advances made in the enzymatic retting methodology, which appears to be the most promising solution. ${ }^{11,12}$ Application of the enzymatic retting methodology has also been studied on hemp $p^{13,14}$ and ramie. ${ }^{15}$

Very few researches have concerned the analysis of nettle fiber quality ${ }^{14,16}$ and, as far as we know, none of them concerned the comparison of different extraction methods and their effects on fiber quality.

The well-known processing methods for flax and hemp could probably be adapted for nettle: ${ }^{16}$ they include water or microbiological retting plus mechanical scutching ${ }^{17}$ and enzymatic processing. ${ }^{5,11,18,19}$ These controlled methods are more expensive than dewretting but, as already mentioned, usually produce better quality fibers. For nettle processing, the high labor costs of water or microbiological retting could be partially offset by the reuse of the waste water because of its positive effects on growth and development of plants ${ }^{20}$ and control of insects, like aphids, ${ }^{21}$ which has also been reported by growers. Both effects could be interesting for sustainable agricultural practices.

An innovative approach that could also be tried on nettle was developed for hemp by the Italian firm Gruppo Fibranova srl (Bientina, Pisa, Italy). They upgraded a traditional retting method by altering the usual sequence of operations adopted in the hemp processing system, ${ }^{22}$ i.e. the scutching was applied on green stems and the resulting raw fibers were processed by a bio-degumming method. The sequence of fiber treatments is important because it can affect the degree of retting.

Detailed assessments of morphological and mechanical properties and chemical composition of fibers obtained from different extraction treatments have mainly been reported for flax.

The aim of this investigation was to evaluate and compare the effects of the application of new or adapted water retting, microbiological, enzymatic and mechanical methodologies on fiber quality of a selected clone of fiber nettle. Fiber quality was evaluated in terms of morphological and mechanical properties and chemical composition, with a focus on hemicellulose, cellulose and lignin content, since fiber performance depends on its chemical composition and physical properties. ${ }^{23}$

\section{Materials and methods}

\section{Plant material}

Fiber nettle plants (clone 13) were cultivated in Prato $\left(43^{\circ} 53^{\prime} \mathrm{N}, 11^{\circ} 06^{\prime} \mathrm{E}\right)$, Italy, on a silt loam soil. Clone 13 was multiplied by vegetative propagation $^{24}$ during winter 2005-2006 and then transplanted into the experimental field on 25th May 2007 at a planting density of $50 \times 75 \mathrm{~cm}(50 \mathrm{~cm}$ on the row and $75 \mathrm{~cm}$ between the rows). No sampling was carried out in the first year because nettle stalks were branched and, according to Bredemann, ${ }^{25}$ the fiber quality is not good. After harvesting on 23rd July 2008, the nettle stalks were dried naturally, stored indoors and used for the subsequent phases of fiber extraction that took place one year later.

\section{First experiment}

Chemical retting. Chemical fiber extraction was performed by applying the processing method developed by Bredemann ${ }^{1}$ for hemp, but with shortening of the immersion time in $2 \% \mathrm{NaOH}$ solution.

A sample of five or 10 nettle stalks was used for each extraction. Each sample was weighed before processing. Five or 10 additional stalks were used to measure the moisture content of the samples, from the mean value of which the dry weight of all samples was calculated.

The extraction method consisted of a pre-treatment in a bath filled with $250 \mathrm{~mL}$ of a $0.35 \%$ soda solution (3.5 g sodium carbonate, $\mathrm{Na}_{2} \mathrm{CO}_{3}$, per $1000 \mathrm{~mL}$ of water) at $100^{\circ} \mathrm{C}$ for $1 \mathrm{~h}$, and a treatment in $\mathrm{NaOH}$ solution. After the pre-treatment, the stalk bark was completely peeled off. In the treatment in $\mathrm{NaOH}$ 
solution, the bark was placed in a screw-cap glass bottle with $250 \mathrm{~mL}$ of $2 \% \mathrm{NaOH}$ solution $(20 \mathrm{~g}$ sodium hydroxide per $1000 \mathrm{~mL}$ of water). The glass bottles were hermetically sealed and placed in a stainless steel pot filled with water to cover the lower half of the bottles. Bottles were treated in boiling water for $50 \mathrm{~min}$, then fiber bundles were removed using pliers and placed on a brass wire strainer (12 wires per $\mathrm{cm}$ ). Finally, fiber bundles were washed for 5-8 min with water under pressure and oven-dried for $48 \mathrm{~h}$ at $60^{\circ} \mathrm{C}$.

Water retting. A glass tank $(30 \mathrm{~L})$ filled with $20 \mathrm{~L}$ of well-water and heated to $28^{\circ} \mathrm{C}$ was used to ret nettle stems. The tank was covered with a transparent glass lid to maintain the water temperature constant.

$1.1 \mathrm{~kg}$ of nettle stalks were placed in $20 \mathrm{~L}$ of water and left there until the bark was easily removed from the core by rubbing the stalk with one's fingers. The stalks were then extracted from the tank and dried at $60^{\circ} \mathrm{C}$ for $48 \mathrm{~h}$.

After drying, fibers were mechanically separated from the residual core by hackling with a laboratory machine used for hemp. Subsequently, part of the fibers was analyzed while the rest was treated enzymatically.

Controlled microbiological retting. Two different polygalacturonase-producing bacteria, ROO40B and L 1/6, isolated from the liquor of hemp, ${ }^{26}$ were used to verify their positive effect on the reduction of water retting time and on the improvement of fiber quality, as already found on hemp. ${ }^{17,26}$ ROO40B is an aerobic pectinolytic strain and $\mathrm{L} 1 / 6$ is an anaerobic one.

Some potatoes were purchased from a local market, peeled and then sterilized with smooth steam. After cooling, they were inoculated using $0.5 \mathrm{~mL}$ of an $\mathrm{L} 1 / 6$ spore suspension. Inoculations were done in order to have a concentration of $10^{4}$ spore per $\mathrm{mL}$ in the tanks.

Potato cultures were incubated at $36^{\circ} \mathrm{C}$ for one week, then filtered and kept refrigerated in a plastic bottle at $4{ }^{\circ} \mathrm{C}$.

As for water retting, $1.1 \mathrm{~kg}$ of nettle stems were put in three covered glass tanks (30 L) filled with $20 \mathrm{~L}$ of well-water and constantly heated at $28^{\circ} \mathrm{C}$. Tanks were inoculated with (1) ROO40B only, (2) L 1/6 only and (3) ROO40B plus L 1/6.

After retting, nettle stalks were extracted from the tanks, and fibers were manually separated. They were then washed with running water for 5-8 min and dried at $60^{\circ} \mathrm{C}$ for $48 \mathrm{~h}$.

Enzymatic treatments of water retted fibers. Enzymatic treatment was performed with Pectinex ${ }^{\circledR}$ Ultra SP-L (Sigma Aldrich, Milan, Italy) and Viscozyme ${ }^{\circledR}$ L (Sigma Aldrich, Milan, Italy), two different enzyme products containing pectinase and hemicellulase, on fibers extracted according to the procedure described in the section on water retting.

Viscozyme ${ }^{\circledR} \mathrm{L}$ is a multienzymatic solution containing a wide range of carbohydrases, including arabase, cellulose, $\beta$-glucanase, hemicellulase and xylase (information from supplier's sheet), already tested by different authors in flax fiber extraction. ${ }^{27-30}$ Pectinex $^{\circledR}$ Ultra SP-L is a highly active pectolytic enzyme preparation produced by a selected strain of Aspergillus aculeatus that contains pectolytic and a range of hemicellulolytic activities (information from supplier's sheet). The solutions ( $350 \mathrm{~mL} / 10 \mathrm{~g}$ fibers) were prepared with $0.05 \mathrm{M}$ sodium acetate buffer $\left(\mathrm{pH}\right.$ 5.0) and Pectinex ${ }^{\circledR}$ Ultra SP-L or Viscozyme ${ }^{\circledR} \mathrm{L}(0.1 \mathrm{~g}$ enzyme solution $/ 10 \mathrm{~g}$ fibers $){ }^{31}$

Fiber samples were incubated in glass bottles with enzyme solutions based on: (1) Pectinex ${ }^{\circledR}$ Ultra SP-L, (2) Pectinex ${ }^{\circledR}$ Ultra SP-L plus $50 \mathrm{mM}$ ethylenediaminetetraacetic acid (EDTA), (3) Viscozyme $^{\circledR}$ L, (4) Viscozyme $^{\circledR}$ L plus $50 \mathrm{mM}$ EDTA. EDTA was added to verify the positive influence of chelating agents on nettle fiber extraction, as already tested on flax. ${ }^{27,32,33}$ The enzymatic treatments were performed at $20{ }^{\circ} \mathrm{C}$ for $24 \mathrm{~h}$ with mechanical agitation. While $20^{\circ} \mathrm{C}$ is the optimum temperature for the activities of the enzymes contained in the Pectinex ${ }^{\circledR}$ Ultra SP-L solution, a temperature of $40-50{ }^{\circ} \mathrm{C}$ would be needed for the maximum activity efficiency of the enzymes contained in the Viscozyme ${ }^{\circledR}$ L mixture. Nevertheless, we preferred to also use a temperature of $20^{\circ} \mathrm{C}$ for Viscozyme ${ }^{\circledR} \mathrm{L}$, since reports indicate that enzymatic retting at a lower temperature for longer times might be advantageous in controlling the process. ${ }^{34}$

After $24 \mathrm{~h}$ fibers were rinsed four times in bidistillated water and dried in an oven at $60^{\circ} \mathrm{C}$ for $48 \mathrm{~h}$.

\section{Second experiment}

Water retting and decortication. Water retting was performed as described in a previous section of the first experiment but, after drying, fibers were mechanically separated from the residual core by scutching with a laboratory machine designed and built for nettle. This was due to the fact that the machine used in the first experiment, developed for hemp stalk decortication, showed some difficulties in nettle processing since the stems were thinner than hemp ones and the machine had no regulation of the distance between timing rollers.

The machine built for nettle (Figure 1 and 2) had three timing rollers that rotated on a timing belt allowing the progress and decortication of the stalks. A regulation system allowed the distance between rollers and timing belt to be modified according to the diameter of the material to be processed. At the end of the timing belt, a harsh brush helped separate the fibers from the wood shives. 


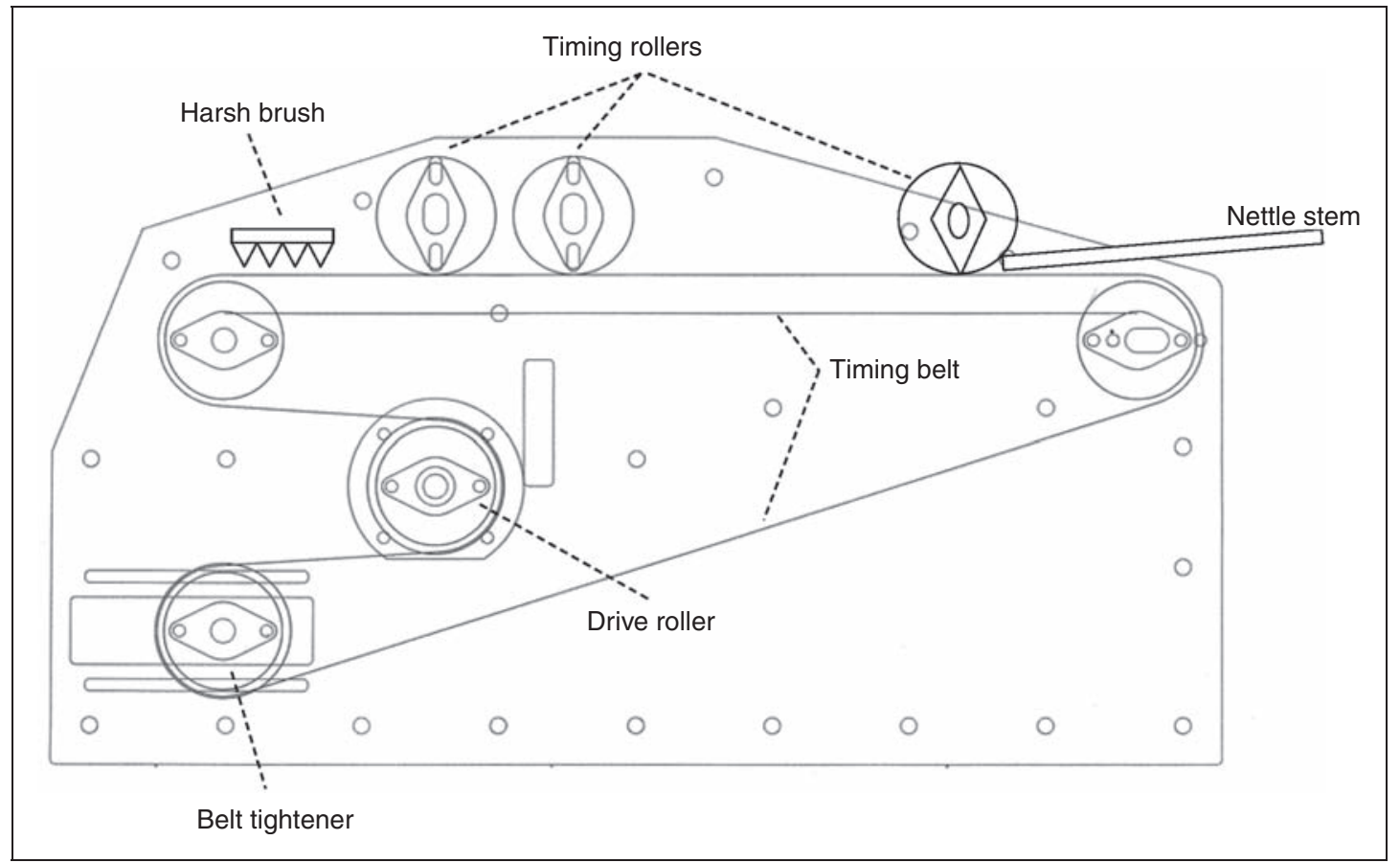

Figure I. Simplified drawing of laboratory scutcher designed and built for nettle processing (lateral section).

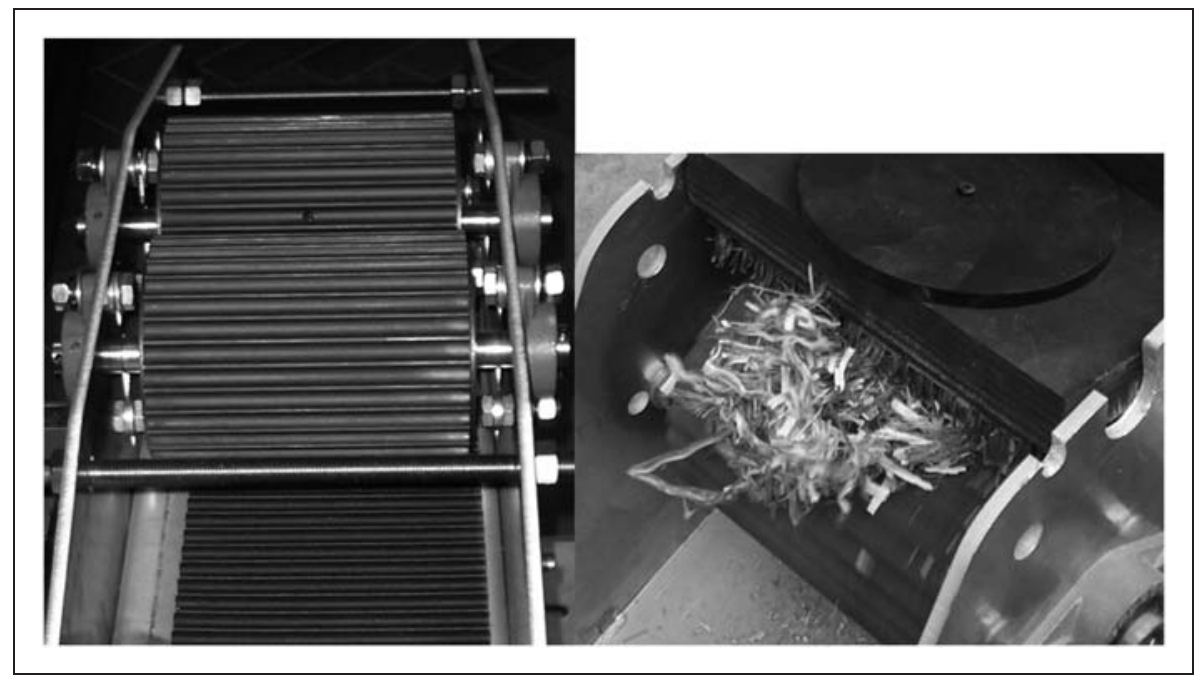

Figure 2. Particulars of laboratory scutcher: timing rollers on the timing belt (left) and harsh brush placed at the end of the timing belt (right).

Decorticated fiber. Dry nettle stems were mechanically separated from the residual core by hackling with the laboratory scutcher. Part of the fiber was then analyzed, the rest was water, controlled microbiological and enzymatically retted (as described in the following sections).

Decorticated fiber and water retting. $15 \mathrm{~g}$ of decorticated fiber (see previous section) were put in covered glass tanks $(1 \mathrm{~L})$ filled with $1 \mathrm{~L}$ of well-water and constantly heated at $28^{\circ} \mathrm{C}$.
After retting (three days later, when the residual shives were easily removable and fiber bundles could be separated by rubbing them with one's fingers), nettle fibers were extracted from the tanks, washed with running water for $5-8 \mathrm{~min}$ and dried at $60^{\circ} \mathrm{C}$ for $48 \mathrm{~h}$.

Decorticated fiber and controlled microbiological retting. Two polygalacturonase-producing bacteria, ROO40B and $13 \mathrm{~A}$, were used to verify the improvement in fiber quality by controlled microbiological 
retting. $\mathrm{ROO} 40 \mathrm{~B}$ is the aerobic pectinolytic strain already used in the first experiment, while $13 \mathrm{~A}$ is an anaerobic one isolated from the liquor of nettle water retting tanks following a similar procedure to that used by Tamburini. ${ }^{26}$ The latter was the best pectinolytic strain as observed from the pectinolytic activity test. ${ }^{7}$

To increase the number of anaerobic cells the same procedure as described for the controlled microbiological retting in the first experiment was used.

$15 \mathrm{~g}$ of mechanically separated nettle fiber (see section on 'decorticated fiber') was put into three covered glass tanks $(1 \mathrm{~L})$ filled with $1 \mathrm{~L}$ of well-water and constantly heated at $28^{\circ} \mathrm{C}$. Tanks were inoculated with about $10^{5}$ spores per $\mathrm{mL}$ with (1) $13 \mathrm{~A}$ only and (2) ROO40B plus 13A.

After retting (also in this case, three days later, when the residual shives were easily removable and fiber bundles could be separated by rubbing them with one's fingers), nettle fibers were washed with running water for 5-8 min and dried at $60^{\circ} \mathrm{C}$ for $48 \mathrm{~h}$.

Decorticated fiber and enzymatic treatments. Mechanically separated nettle fiber (see section on 'decorticated fiber') was enzymatically treated with Pectinex ${ }^{\circledR}$ Ultra SP-L (Sigma Aldrich, Milan, Italy) and Viscozyme ${ }^{\circledR}$ L (Sigma Aldrich, Milan, Italy).

The first treatment was performed as described previously with enzyme solutions based on (1) Pectinex ${ }^{\circledR}$ Ultra SP-L plus $50 \mathrm{mM}$ ethylenediaminetetraacetic acid (EDTA) and (2) Viscozyme ${ }^{\circledR}$ L plus $50 \mathrm{mM}$ EDTA at $20^{\circ} \mathrm{C}$ for $24 \mathrm{~h}$ in mechanical agitation. After $24 \mathrm{~h}$, fibers were rinsed four times in bidistillated water and dried at room temperature (about $20^{\circ} \mathrm{C}$ ).

Other samples of decorticated nettle fiber were treated with other formulations of the above-mentioned enzyme products following a method similar to that developed by Akin et $a l .{ }^{35}$ for flax. The formulations were composed of $0.05 \mathrm{M}$ sodium acetate buffer $(\mathrm{pH}$ 5.0). Fiber was sprayed with the formulation at a ratio of $66 \mathrm{~mL}$ per $20 \mathrm{~g}$ fiber with a hand-held sprayer. The enzyme treated fiber samples were allowed to soak for $60 \mathrm{sec}$, drained for about $30 \mathrm{sec}$ to remove excess liquid, divided into two parts and sealed in plastic bags. One part was incubated at $40^{\circ} \mathrm{C}$ for $24 \mathrm{~h}$, the other was maintained at room temperature (about $20^{\circ} \mathrm{C}$ ) for $48 \mathrm{~h}$. After incubation, the enzyme retted fibers were washed by immersion in bidistilled water (about 30-60 sec), then rinsed for 30-60 sec under running water and air dried (about $20^{\circ} \mathrm{C}$ ).

Determination of morphological, chemical and mechanical properties of fiber samples. Fibers obtained from each extraction method were analyzed to determine their morphological, chemical and mechanical properties.
About $4 \mathrm{~g}$ of every fiber sample were analyzed by a FibertecTM analyzer (FOSS Group, Denmark), according to Van Soest's method ${ }^{36}$, to determine cellulose, hemicellulose and lignin content. Hemicellulose and cellulose contents were calculated from acid detergent fiber (ADF), neutral detergent fiber (NDF) and acid detergent lignin (ADL) measurements as NDF$\mathrm{ADF}$ and $\mathrm{ADF}-\mathrm{ADL}$ for hemicellulose and cellulose, respectively.

Diameters and lengths of 50 fibers, selected with the aid of a stereomicroscope $(57 \times)$, were measured by an ocular micrometer. Since the diameter of bast fibers was not uniform, the diameter of each fiber was measured at different places and the average value was used. We chose the diameter to describe the morphological characteristics of the fiber instead of linear density, which would have been a better descriptive parameter, in accordance with the few data available in the literature on nettle fiber.

The tensile properties of filaments, strength and elongation, were determined on 50-fiber samples with an Instron 4301-CRE dynamometer according to the UNI EN ISO 5079-98 standard.

Statistical analysis. Statistical analysis was carried out with one-way ANOVA using the program Statistica 6.0 (StatSoft, 2003). A comparison of individual means was then performed using Tukey's test. Means were considered different at probability values of $p<0.05$.

\section{Results and discussion}

A high variability was found within each fiber sample (Tables 1-6) of both experiments in all measured parameters, and especially in mechanical properties, independently of the fiber extraction method applied. Dispersion of mechanical properties is inevitable with vegetable fibers, ${ }^{37}$ even when the different parts of the stalks (bottom, middle and top) are analyzed separately. ${ }^{2}$

\section{First experiment}

The first result observed was that microbiological inoculation did not reduce the retting time in comparison with water retting, disagreeing with results reported for controlled retting of hemp, ${ }^{17}$ as in both cases the retting was completed after three days. Fibers extracted by the microbiological method generally showed significantly lower diameter values (treatments C, D and E, Table 1) and higher lignin content (treatments $\mathrm{C}$ and $\mathrm{D}$, Table 2), except when both bacteria were used contemporarily (treatment E, Table 2). The diameter of microbiological-retted fibers was about $10 \mu \mathrm{m}$ less than water-retted ones (24-31 $\mu \mathrm{m}$ vs. $37-41 \mu \mathrm{m})$. 
Table I. First experiment. Morphological and mechanical properties of fibers extracted with different methods. Means followed by different letters within a column differ significantly (at least $p=0.05$ ) according to ANOVA

\begin{tabular}{|c|c|c|c|c|}
\hline \multirow[b]{2}{*}{ Treatment } & \multicolumn{2}{|c|}{ Morphological properties } & \multicolumn{2}{|l|}{ Mechanical properties } \\
\hline & Diameter $(\mu \mathrm{m})$ & Length $(\mathrm{mm})$ & Tenacity (cN tex ${ }^{-1}$ ) & Elongation (\%) \\
\hline A & $30 \pm 7$ abe & $50 \pm 12 \mathrm{a}$ & $59.3 \pm 21.3 a$ & $5.6 \pm 1.2 \mathrm{a}$ \\
\hline B & $39 \pm 2 \mathrm{ac}$ & $45 \pm 4 a$ & $51.4 \pm 43.0 \mathrm{a}$ & $3.2 \pm 0.9 b c d$ \\
\hline C & $25 \pm \mathrm{Ib}$ & $47 \pm 6 a$ & $44.8 \pm 6.0 \mathrm{a}$ & $3.4 \pm 1.0 \mathrm{bc}$ \\
\hline D & $28 \pm 3 b$ & $5 \mathrm{I} \pm 4 \mathrm{a}$ & $48.6 \pm 16.0 \mathrm{a}$ & $3.4 \pm 0.8 \mathrm{bcd}$ \\
\hline$E$ & $27 \pm \mathrm{Ib}$ & $50 \pm 5 a$ & $42.5 \pm 5.9 \mathrm{a}$ & $2.6 \pm 0.5 b$ \\
\hline $\mathrm{F}$ & $32 \pm 2 \mathrm{abe}$ & $47 \pm 5 a$ & $46.6 \pm 25.7 a$ & $4.1 \pm 1.5 c d$ \\
\hline $\mathrm{FI}$ & $28 \pm 3 b$ & $47 \pm 4 \mathrm{a}$ & $43.9 \pm 11.7 a$ & $3.8 \pm 0.7 \mathrm{bcd}$ \\
\hline G & $39 \pm I c e$ & $49 \pm 3 a$ & $40.5 \pm 16.4 a$ & $3.6 \pm 0.9 \mathrm{bcd}$ \\
\hline GI & $33 \pm 2$ bde & $46 \pm 4 a$ & $58.9 \pm 16.8 \mathrm{a}$ & $4.9 \pm 1.3 \mathrm{ad}$ \\
\hline
\end{tabular}

$A$, chemical retting; $B$, water retting; C, microbiological retting with ROO40B; D, microbiological retting with $L$ I/6; E, microbiological retting with ROO40B plus L I/6; F, enzymatic retting with Viscozyme ${ }^{\circledR}$ L; FI, enzymatic retting with Viscozyme ${ }^{\circledR}$ L plus EDTA; G, enzymatic retting with Pectinex ${ }^{\circledR}$ Ultra SP-L; GI, enzymatic retting with Pectinex ${ }^{\circledR}$ Ultra SP-L plus EDTA.

Table 2. First experiment. Chemical composition (\%) in cellulose, hemicellulose and lignin of the fibers extracted with different methods

\begin{tabular}{llll}
\hline Treatment & Cellulose (\%) & Hemicellulose (\%) & Lignin (\%) \\
\hline A & 81.3 & 5.9 & 2.2 \\
B & 78.4 & 9.4 & 2.8 \\
C & 79.6 & 8.9 & 3.6 \\
D & 78.1 & 10 & 5.2 \\
E & 84.4 & 8.5 & 2 \\
F & 81.6 & 12.1 & 2.1 \\
FI & 82.7 & 12 & 2.1 \\
G & 80 & 11.8 & 2.5 \\
GI & 80.8 & 11.1 & 2.8 \\
\hline
\end{tabular}

$A$, chemical retting; $B$, water retting; $C$, microbiological retting with ROO40B; D, microbiological retting with $L$ I/6; E, microbiological retting with ROO40B plus L I/6; F, enzymatic retting with Viscozyme ${ }^{\circledR}$ L; FI, enzymatic retting with Viscozyme ${ }^{\circledR}$ L plus EDTA; G, enzymatic retting with Pectinex ${ }^{\circledR}$ Ultra SP-L; GI, enzymatic retting with Pectinex ${ }^{\circledR}$ Ultra SP-L plus EDTA.

The enzyme treatments were applied to water-retted fibers to verify the possibility of improving fiber fineness without affecting the mechanical characteristics. Indeed, some authors ${ }^{38,39}$ recommend enzyme application to restore the quality of badly degummed retted fibers at the scutched fiber stage, improving their fineness, color and cleanness.

Comparison of the two images (Figure 3) already illustrates the effects of enzyme treatment on waterretted fibers. Indeed, the enzyme treated fibers appear softer.

Concerning the differences of fiber characteristics, a significant reduction in fiber diameter was detected in
Table 3. Second experiment - part I. Morphological and mechanical properties of fibers extracted with different methods. Means followed by different letters within a column differ significantly (at least $p=0.05$ ) according to ANOVA

\begin{tabular}{|c|c|c|c|c|}
\hline \multirow[b]{2}{*}{ Treatment } & \multicolumn{2}{|c|}{$\begin{array}{l}\text { Morphological } \\
\text { properties }\end{array}$} & \multicolumn{2}{|l|}{$\begin{array}{l}\text { Mechanical } \\
\text { properties }\end{array}$} \\
\hline & $\begin{array}{l}\text { Diameter } \\
(\mu \mathrm{m})\end{array}$ & $\begin{array}{l}\text { Length } \\
(\mathrm{mm})\end{array}$ & $\begin{array}{l}\text { Tenacity } \\
\left(\mathrm{cN} \text { tex }^{-1}\right)\end{array}$ & $\begin{array}{l}\text { Elongation } \\
(\%)\end{array}$ \\
\hline $\mathrm{H}$ & $36 \pm 7 a b$ & $45.0 \pm 9.7 \mathrm{a}$ & $47.2 \pm 23.9 b c$ & $\mathrm{I} . \mathrm{I} \pm 0.6 \mathrm{bc}$ \\
\hline I & $35 \pm 12 b$ & $41.7 \pm 16.6 a$ & $126.1 \pm 55.7 b$ & $2.4 \pm 0.9 b$ \\
\hline J & $43 \pm 3 a b$ & $48.0 \pm 10.4 a$ & $62.1 \pm 21.3 a$ & $\mathrm{I} .5 \pm 0.9 \mathrm{a}$ \\
\hline K & $28 \pm 12 \mathrm{a}$ & $48.3 \pm 11.8 \mathrm{a}$ & $64.0 \pm 33.6 c$ & $0.8 \pm 0.4 b$ \\
\hline $\mathrm{L}$ & $29 \pm 10 \mathrm{a}$ & $42.7 \pm 9.5 a$ & $29.1 \pm 22.1 \mathrm{c}$ & $0.9 \pm 0.7 c$ \\
\hline
\end{tabular}

$\mathrm{H}$, water retted and decorticated fibers; I, decorticated fibers without retting; J, decorticated and water retted fibers; $K$, decorticated fibers retted with I3A; L, decorticated fibers retted with ROO40B plus I3A.

enzyme treated fibers in comparison with fibers obtained by water retting alone, but only when EDTA was added: the mean values were $28 \mu \mathrm{m}$ and $33 \mu \mathrm{m}$ for Viscozyme ${ }^{\circledR}$ L plus EDTA (treatment F1, Table 1) and Pectinex ${ }^{\circledR}$ Ultra SP-L plus EDTA (treatment G1, Table 1) respectively, in comparison with a mean diameter of $39 \mu \mathrm{m}$ shown by water retted fibers.

As previously detected for flax, ${ }^{32,40}$ the adding of EDTA, as a chelator, to pectinase-containing enzyme mixtures facilitated the disruption of internal plant cell walls and increased retting efficiency, fiber quality and, consequently, economic attractiveness at a commercial level. A mixture of chelators and enzymes can be very efficient, since the galacturonic residues of pectic substances in the natural environment form aggregates with $\mathrm{Ca}^{2+}$ that crosslinks pectin chains with each 
Table 4. Second experiment - part I. Chemical composition (\%) in cellulose, hemicellulose and lignin of the fibers extracted with different methods

\begin{tabular}{llcl}
\hline Treatment & Cellulose (\%) & Hemicellulose (\%) & Lignin (\%) \\
\hline $\mathrm{H}$ & 86.3 & 6.4 & 3.6 \\
$\mathrm{I}$ & 65.3 & 5.2 & 2.9 \\
$\mathrm{~J}$ & 83.3 & 12.5 & 1.6 \\
$\mathrm{~K}$ & 74.9 & 6.5 & 3.7 \\
$\mathrm{~L}$ & 85 & 5.2 & 2.9 \\
\hline
\end{tabular}

$\mathrm{H}$, water retted and decorticated fibers; I, decorticated fibers without retting; J, decorticated and water retted fibers; $K$, decorticated fibers retted with I3A; L, decorticated fibers retted with ROO40B plus I3A.

Table 5. Second experiment - part II. Morphological and mechanical properties of fibers extracted with different methods. Means followed by different letters within a column differ significantly (at least $p=0.05$ ) according to ANOVA

\begin{tabular}{|c|c|c|c|c|}
\hline \multirow[b]{2}{*}{ Treatment } & \multicolumn{2}{|c|}{$\begin{array}{l}\text { Morphological } \\
\text { properties }\end{array}$} & \multicolumn{2}{|l|}{$\begin{array}{l}\text { Mechanical } \\
\text { properties }\end{array}$} \\
\hline & $\begin{array}{l}\text { Diameter } \\
(\mu \mathrm{m})\end{array}$ & $\begin{array}{l}\text { Length } \\
(\mathrm{mm})\end{array}$ & $\begin{array}{l}\text { Tenacity } \\
\left(\mathrm{cN} \text { tex }^{-1}\right)\end{array}$ & $\begin{array}{l}\text { Elongation } \\
(\%)\end{array}$ \\
\hline I & $35 \pm 12 a b$ & $41.7 \pm 16.6 a$ & $|26.| \pm 55.7 \mathrm{a}$ & $2.4 \pm 0.9 a$ \\
\hline$M$ & $30 \pm 5 a$ & $41.8 \pm 5.3 a$ & $38.8 \pm 16.3 b$ & $1.3 \pm 0.6 \mathrm{~b}$ \\
\hline $\mathrm{N}$ & $33 \pm 5 a c$ & $47.2 \pm 13.2 \mathrm{a}$ & $20.2 \pm 12.0 c$ & $1.6 \pm 0.5 b$ \\
\hline MI & $43 \pm 5 b$ & $53.7 \pm 5.6 a$ & $22.2 \pm 10.8 c$ & $0.7 \pm 0.5 c$ \\
\hline$M 2$ & $4 I \pm 9 b c$ & $51.2 \pm 11.2 \mathrm{a}$ & $18.7 \pm 10.7 c$ & $0.8 \pm 0.5 c$ \\
\hline $\mathrm{NI}$ & $40 \pm 8 b c$ & $52.3 \pm 9.5 a$ & $25.5 \pm 10.8 \mathrm{cb}$ & $1.3 \pm 0.5 b$ \\
\hline N2 & $43 \pm 6 b$ & $43.5 \pm 6 a$ & $21.1 \pm 12.8 c$ & $1.2 \pm 0.6 \mathrm{~b}$ \\
\hline
\end{tabular}

I, decorticated fibers without retting; $M$, decorticated fibers vat-retted with Pectinex ${ }^{\circledR}$ Ultra SP-L plus EDTA; N, decorticated fibers vat-retted with Viscozyme ${ }^{\circledR}$ L plus EDTA; MI, decorticated fibers retted with Pectine ${ }^{\circledR}$ Ultra SP-L plus EDTA (spray distribution and storage at ambient temperature for $48 \mathrm{~h}$ ); $M 2$, decorticated fibers retted with Pectinex ${ }^{\circledR}$ Ultra SP-L plus EDTA (spray distribution and storage at $40^{\circ} \mathrm{C}$ for $24 \mathrm{~h}$ ); $\mathrm{NI}$, decorticated fibers retted with Viscozyme ${ }^{\circledR}$ L plus EDTA (spray distribution and storage at ambient temperature for $48 \mathrm{~h}$ ); N2, decorticated fibers retted with Viscozyme ${ }^{\circledR} \mathrm{L}$ plus EDTA (spray distribution and storage at $40^{\circ} \mathrm{C}$ for $24 \mathrm{~h}$ ).

other and reduces the action of polygalacturonase. ${ }^{41,42}$ By chelating the metal ions from the pectin complex, non-cellulosic plant pectins and hemicelluloses can be extracted, thus leaving fiber celluloses free of pectins and hemicelluloses. ${ }^{43}$ Actually most of the pectin from the fiber can be hydrolyzed to improve fiber fineness, but only a limited proportion (almost 10\%) of hemicelluloses can be removed during retting or chemical processing without causing a reduction in fiber strength. ${ }^{44}$ In fact the hemicelluloses are integral components of the fiber cell walls and thereby provide
Table 6. Second experiment - part II. Chemical composition (\%) in cellulose, hemicellulose and lignin of the fibers extracted with different methods

\begin{tabular}{llcl}
\hline Treatment & Cellulose (\%) & Hemicellulose (\%) & Lignin (\%) \\
\hline I & 65.3 & 5.2 & 2.9 \\
M & 82 & 4.4 & 3.4 \\
N & 83.2 & 5.4 & 3.3 \\
MI & 79.3 & 6.4 & 4 \\
M2 & 78.6 & 2.3 & 3 \\
NI & 74.4 & 11.1 & 3.8 \\
N2 & 75.9 & 4.8 & 3.1 \\
\hline
\end{tabular}

I, decorticated fibers without retting; $M$, decorticated fibers vat-retted with Pectinex ${ }^{\circledR}$ Ultra SP-L plus EDTA; $N$, decorticated fibers vat-retted with Viscozyme ${ }^{\circledR}$ L plus EDTA; MI, decorticated fibers retted with Pectinex ${ }^{\circledR}$ Ultra SP-L plus EDTA (spray distribution and storage at ambient temperature for $48 \mathrm{~h}$ ); $M 2$, decorticated fibers retted with Pectinex ${ }^{\circledR}$ Ultra SP-L plus EDTA (spray distribution and storage at $40^{\circ} \mathrm{C}$ for $24 \mathrm{~h}$ ); $\mathrm{NI}$, decorticated fibers retted with Viscozyme ${ }^{\circledR}$ L plus EDTA (spray distribution and storage at ambient temperature for $48 \mathrm{~h}$ ); N2, decorticated fibers retted with Viscozyme ${ }^{\circledR} \mathrm{L}$ plus EDTA (spray distribution and storage at $40^{\circ} \mathrm{C}$ for $24 \mathrm{~h}$ ).

strength while pectin is deposited mainly in the middle lamella between the fiber and other cells.

The fiber diameter thinning caused by microbiological or enzymatic activity was probably as a consequence of the isolation of fiber bundles of reduced thickness, as previously found by Hobson ${ }^{45}$, and did not significantly differ from those of fibers obtained by the chemical method usually applied at laboratory scale for pure fiber content determination (treatment A, Table 1). We can therefore suppose that a simple water retting is unable to completely disintegrate pectins that tie fibers in a bundle. However, the fiber diameter obtained by microbiological or enzymatic retting was larger than that found by Dreyer and Müssing ${ }^{14}$ who, applying enzymatic treatments on dew-retted fibers, obtained fibers with a diameter of around 19-20 $\mu \mathrm{m}$. Similar values were detected by Bacci et al., ${ }^{2}$ taking into account only the top part of the stalks. The greater fineness found by Dreyer and Müssing ${ }^{14}$ was however associated to strength values of about $24 \mathrm{cN}$ tex ${ }^{-1}$, much lower than those measured in the present experiment, which ranged from about 40 to $60 \mathrm{cN}$ tex ${ }^{-1}$ for enzyme treated fibers (treatments F1 and G1, Table 1). Chemical-retted fibers showed a mean tenacity of $59 \mathrm{cN}$ tex ${ }^{-1}$, higher than that of $37 \mathrm{cN}$ tex ${ }^{-1}$ measured by Hartl and $\operatorname{Vogl}^{46}$ on nettle fiber extracted with the same method.

Therefore, the greater fineness detected in microbiological and enzymatic treatments in the present experiment did not seem to affect tenacity. For elongation measurements (Table 1), only chemical-retted fibers and fibers treated with Pectinex plus EDTA showed 
mean elongation values significantly higher than almost all the others.

While tenacity values measured in all the treatments were similar to those detected in previous experiments, ${ }^{2}$ elongation values were generally higher. Elongation in textiles is an important property that affects quality and consequently application. Mean elongation values ranged between $5.6 \%$ (treatment A, Table 1) and $2.6 \%$ (treatment E, Table 1) vs. the mean value of $2.5 \%$ previously found in other experiments.

As expected, no significant difference in fiber length was found among treatments (Table 1). Mean lengths ranged between 45 and $50 \mathrm{~mm}$, confirming the values previously found by Bacci et al. ${ }^{2}$

The proportions of cellulose, hemicellulose and lignin fractions differed among treatments (Table 2). Generally, the enzyme application slightly reduced the percentage of lignin content in water-retted fibers, e.g., from $2.8 \%$ in water-retted (treatment B) to $2.1 \%$ in Viscozyme ${ }^{\circledR}$ L plus EDTA treated fibers (treatment F1). A reduction in lignin content was also detected in microbiologically extracted fibers with the combination of aerobic and anaerobic bacteria inoculation (treatment E), that showed a value of $2.0 \%$.

The fibers treated only with the anaerobic strain (L 1/6) showed the highest lignin content (5.2\%). This result was in agreement with the bacterial activity reported versus other components like pectin. ${ }^{17}$

Low lignin content associated with high cellulose and hemicellulose content indicates fibers with a good quality and means that retting has mainly removed pectin and lignin, within non-cellulosic polysaccharides, but only partially hemicelluloses. ${ }^{44}$

\section{Second experiment}

In the second experiment, different retting methods were applied on fiber decorticated mechanically by the dedicated laboratory scutcher. Even before retting, the mechanically decorticated fiber already showed a good degree of separation between fibers and shives (Figure 4) as a consequence of the utilization of stalks harvested one year before and stored in a dry sheltered environment.

We can suppose that a certain amount of degradation would have taken place during that time. Indeed, it has been known for many years that old flax bales ret better than recently baled flax, because recently harvested, non-retted flax has a more intact stalk with little to no degradation. ${ }^{47}$

The water retting of entire stalks followed by mechanical decortication was repeated according to the method applied in the first experiment, but using the laboratory scutcher developed during the project to separate the fibers from wood core and shives.

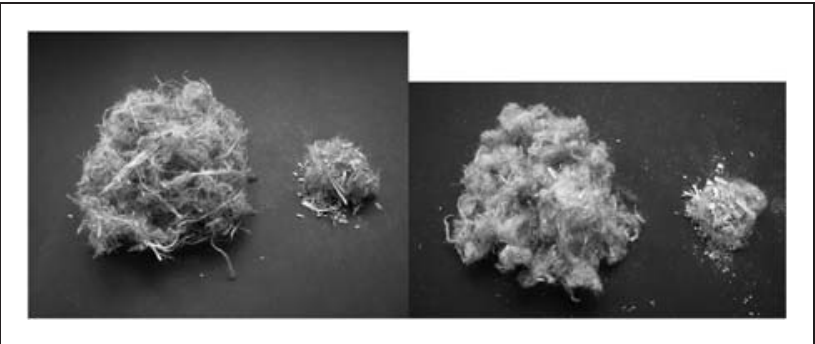

Figure 3. Water retted fiber (on the left) and water retted fiber treated with enzyme (on the right).

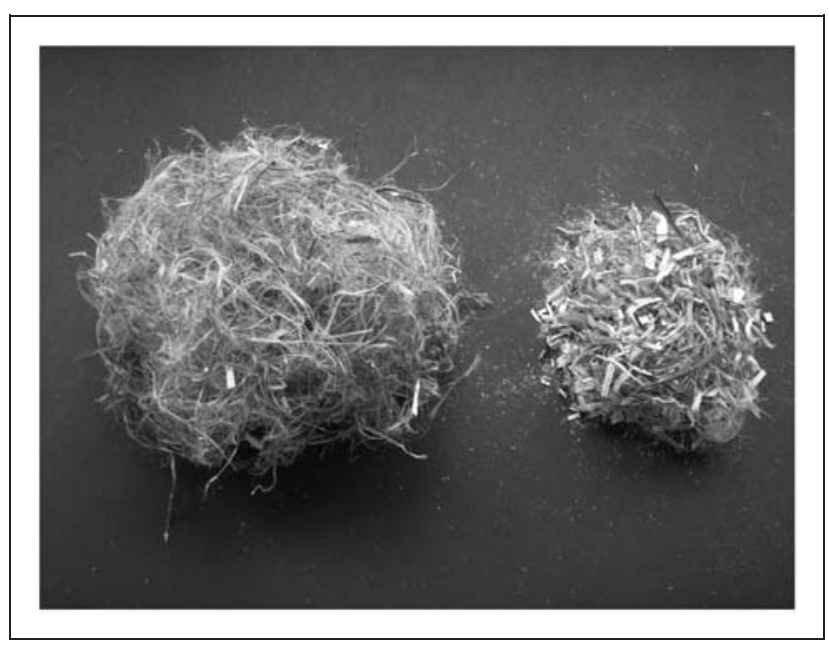

Figure 4. Unretted mechanically decorticated fiber.

The resulting fibers had similar characteristics to those measured in the first experiment (cf. values of treatment B in Table 1 and 2 with values of treatment $\mathrm{H}$ in Table 3 and 4), apart from a higher cellulose content.

Decorticated fibers without retting (treatment I, Table 3) showed a fineness comparable to decorticated and water-retted fibers (treatment J, Table 3 ) and to water-retted and decorticated fibers (treatment $\mathrm{H}$, Table 3), but with a much higher tenacity (Table 3). Nevertheless their cellulose content was much lower (treatment I, Table 4), with a value of about $65 \%$ indicating a poor quality fiber as a consequence of very insufficient degradation of pectins.

The comparison between fibers that had first been water retted and then decorticated (traditional retting method; treatment $\mathrm{H}$ ) and fibers that had first been mechanically decorticated and then water retted (treatment J) showed statistically significant differences for tenacity and elongation values (Table 3 ), with the former having lower mean values than the latter $\left(47.2 \mathrm{cN} \mathrm{tex}^{-1}\right.$ vs. $62.1 \mathrm{cN}$ tex ${ }^{-1}$ and $1.1 \%$ vs. $1.5 \%$, 
respectively), and for lignin content, with higher values for the fiber extracted traditionally $(3.6 \%$ vs. $1.6 \%)$ (Table 4). Taking these results into account, if the unretted dry stalks could be successfully decorticated, this method would have the interesting advantage of reducing the volume of biomass to be retted without negatively affecting mechanical properties.

As in the first experiment, even if not applied to entire stalks but to decorticated fibers, the microbiological retting (treatment $\mathrm{K}$ and $\mathrm{L}$, Table 3 ) determined a significant reduction in fiber diameter that reached a mean value of about $28-29 \mu \mathrm{m}$ vs. mean values of $35 \mu \mathrm{m}$ and $43 \mu \mathrm{m}$ for decorticated (treatment I) and decorticated and water-retted fibers (treatment $\mathrm{J}$ ), with a slightly higher tenacity than that of the latter $\left(64 \mathrm{cN} \mathrm{tex}^{-1}\right.$ vs. $62.0 \mathrm{cN}$ tex $\left.{ }^{-1}\right)$. According to the results of the first experiment (treatment D and E, Table 2), the effects on chemical composition of fibers differed when retting was carried out using only the anaerobic bacteria (treatment $\mathrm{K}$, Table 4) or when the latter was used together with the aerobic one (treatment L, Table 4). In the first case the resulting fibers had lower cellulose content $(74.9 \%$ vs. $85.0 \%)$ and higher lignin content $(3.7 \%$ vs. $2.9 \%)$, which indicated a lower fiber quality.

Few enzymes are known to attack and penetrate the cuticle due to the complex wax and phenolic constituents in this structure. Consequently, all the experiments of enzyme retting are performed on stalks mechanically pretreated to crack the cutinized structure and allow access to the internal cells by enzymes. ${ }^{27,32,35}$

However, according to Akin et al., ${ }^{40}$ mild methods have to be used to facilitate enzyme penetration before retting because overly aggressive methods seem to result in considerable loss of strength. In our experiment, in which enzymatic retting was applied on mechanically decorticated raw fiber, the high textile strength of unretted decorticated fiber (treatment I, Table 5) would seem to indicate that the mechanical treatment applied to the stalks had not compromised this characteristic.

Unlike the results obtained by Akin et al. ${ }^{40}$ in experiments on flax, in which all enzyme treatments resulted in lower diameters than unretted fibers, the application of the two different enzyme mixtures (Pectinex ${ }^{\circledR}$ Ultra SP-L and Viscozyme ${ }^{\circledR}$ L) on unretted decorticated nettle fibers, even with two different methods (spray distribution (treatment M1, M2, N1 and N2) and fiber immersion in the solution (treatment $\mathrm{M}$ and $\mathrm{N}$ )), did not have any significant effect on fiber fineness (Table 5). Nevertheless, decorticated fibers immersed in enzyme solution (treatment $\mathrm{M}$ and $\mathrm{N}$, Table 6) showed a relevant increase in cellulose content compared with treatment I, while hemicellulose and lignin contents were similar, underlining the pectinolytic activities of the enzymes and consequent improvement in fiber quality. Concerning the tenacity, fibers treated with Pectinex ${ }^{\circledR}$ Ultra SP-L plus EDTA (treatment M, Table 5) showed a significantly higher value than fibers treated with Viscozyme ${ }^{\circledR}$ L plus EDTA (treatment N, Table 5). This result could support what is reported in the literature, ${ }^{27}$ i.e. that enzymes containing only pectinases would result in fibers with significantly higher strength than cellulose-containing mixtures.

In comparison with the decorticated fibers immersed in enzyme solutions (treatment $\mathrm{M}$ and $\mathrm{N}$, Table 5 and 6), the spray enzyme treated fibers (M1, M2, N1 and N2, Table 5 and 6) usually showed thicker diameter, lower tenacity values (only for retting with Viscozyme ${ }^{\circledR}$ L plus EDTA) and lower cellulose content. Akin et al., ${ }^{35}$ starting from similar material of flax, also found that spray enzyme retting resulted in coarser fibers and fiber strength about equal to vat retting.

No significant differences were detected between the two methods used to store enzyme sprayed fibers, i.e. fibers stored at $40^{\circ} \mathrm{C}$ for $24 \mathrm{~h}$ and fibers stored at ambient temperature for double that length of time.

Elongation values showed by enzyme treated fibers (treatment M, N, M1, M2, N1, N2) were low in comparison to those found in the first experiment and very similar to those found by Akin et al. ${ }^{35}$ on flax spray enzyme retted fiber $(0.8-1.3 \%)$.

\section{Conclusions}

Once verified on other nettle stalk samples that the mechanical decortication of stalks stored for one year determines a good degree of separation between fibers and shives, this operation could be routinely applied before retting because it would reduce the volume/ weight of biomass to be retted with consequent water and energy saving as well as a relevant reduction of enzyme mixture needed for an enzymatic retting.

Both controlled microbiological retting with the combined use of anaerobic and aerobic bacteria and vat enzymatic retting, especially when a solution of Pectinex ${ }^{\circledR}$ Ultra SP-L plus EDTA was used, determined a similar improvement in fiber quality. On the contrary spray enzyme retting, experimented successfully on flax, resulted in coarser fibers on nettle and, sometimes, with a lower tenacity. Nevertheless, taking into account that this technique would allow a relevant reduction of enzyme quantity to be used, it is worth further investigation, also with other enzyme mixtures on both decorticated unretted fiber and crimped stalks in order to fine-tune a procedure that guarantees a high quality of nettle fibers at lower cost.

\section{Acknowledgments}

The authors wish to express their appreciation to F. Sabatini and M. Lanini for their support in field activities, C. Indorato for her technical assistance in the microbiological laboratory. 


\section{Funding}

This work was supported by Tuscany Region (grant number 1768/2008) and the Ministry of Scientific Research (grant number 12999/2010).

\section{Literature cited}

1. Bredemann G. Die Bestimmung des Fasergehaltes bei Massenuntersuchungen von Hanf, Flachs. Fasernesseln und anderen Bastfaserpflanzen. Faserforschung 1942; 16: 14-39.

2. Bacci L, Baronti S, Predieri S and Di Virgilio N. Fiber yield and quality of fiber nettle (Urtica dioica L.) cultivated in Italy. Ind Crops Prod 2009; 29(2-3): 480-484.

3. Pinelli P, Ieri F, Vignolini P, Bacci L, Baronti $\mathrm{S}$ and Romani A. Extraction and HPLC analysis of secondary metabolites in leaves, stalks and textile fibers of Urtica dioica L. J Agric Food Chem 2008; 56: 9127-9132.

4. Pallesen BE. The quality of combine-harvested fiber flax for industrial purposes depends on the degree of retting. Ind Crops Prod 1996; 5: 65-78.

5. Van Sumere CF. Retting of flax with special reference to enzyme retting. In: Sharma HSS and Van Sumere CF (eds) The biology and processing of flax. Belfast: $\mathrm{M}$. Publications, 1992, pp.157-192 (1992).

6. Henriksson G, Akin DE, Hanlin RT, Rodriguez C, Archibald DD, Rigsby LL, et al. Identification and retting efficiency of fungi isolated from dew-retted flax in the United States and Europe. Appl Environ Microbiol 1997; 63: 3950-3956.

7. Donaghy JA, Levette PN and Haylock RW. Changes in microbial populations during anaerobic flax retting. $J$ Appl Bacteriol 1990; 69: 634-641.

8. Donaghy JA, Boomer JH and Haylock RW. An assessment of the quality and yield of flax fiber produced by the use of pure bacterial cultures in flax rets. Enzyme Microb Technol 1992; 14: 131-134.

9. Bratt RP, Mercer PC and Brown A. Degradation of flax stems by Botrytis cinerea. Trans Br Mycol Soc 1988; 90(4): 537-544.

10. Gillespie AM, Keane D, Griffin TO, Tuohy MG, Donaghy J, Haylock RW, et al. The application of fungal enzymes in flax retting and the properties of an extracellular polygalacturonase from Penicillium capsulatum. In: Kirk TK and Chang HM (eds) Biotechnology in pulp and paper manufacture. Stoneham: ButterworthHeinemann, 1990, pp.211-219.

11. Akin DE, Foulk JA, Dodd RB and McAliser III DD. Enzyme retting of flax and characterization of processed fibers. J Biotechnol 2001; 89: 193-203.

12. Sharma HSS, Whiteside L and Kernaghan K. Enzymatic treatment of flax fiber at the roving stage for production of wet-spun yarn. Enzym Microb Tech 2005; 37: 386-394.

13. Fischer H, Müssing J, and Bluhm C. Enzymatic modification of hemp fibres for sustainable production of high quality materials: influence of processing parameters. $3^{\text {rd }}$ International Conference on Textile Biotechnology, 13-16 June, Graz, Austria, 2004.

14. Dreyer J, and Müssing J. New horizons in natural fiber production: retting hemp and nettle with enzymes. $3^{\text {rd }}$ International Symposium Bioresource Hemp and Other Fibre Plants, September 13-16, Wolfsburg, Germany, 2000.

15. Brühlmann F, Leupin M, Erismann KH and Fiechter A. Enzymatic degumming of ramie bast fibers. J Biotechnol 2000; 76: 43-50.

16. Vogl CR and Hartl A. Production and processing of organically grown fiber nettle (Urtica dioica L.) and its potential use in the natural textile industry: a review. Am. J Altern Agric 2003; 18: 119-128.

17. Di Candilo M, Ranalli P, Bozzi C, Focher B and Mastromei G. Preliminary results of tests facing with the controller retting of hemp. Ind Crops Prod 2000; 11: 197-203.

18. Kashyap DR, Vohra PK, Chopra S and Tewari R. Applications of pectinases in the commercial sector: a review. Bioresource Technol 2001; 77: 215-227.

19. Hoondal GS, Tiwari RP, Tewari R and Dahiya N. Microbial alkaline pectinases and their industrial applications: a review. Appl Microbiol Biotechnol 2002; 59: 409-418.

20. Peterson $\mathrm{R}$ and Jensén P. Effects of nettle water on growth and mineral nutrition of plants. I Composition and properties of nettle water. Biol Agric Hortic 1986; 2: 303-314.

21. Gaspari M, Lykouressis D, Perdikis D and Polissiou M. Nettle extract effects on the aphid Myzus persicae and its natural enemy, the predator Macrolophus pygmaeus (Hem., Miridae). J Appl Entomol 2007; 131(9-10): 652-657.

22. Tofani C. Processing of hemp textile fibres: tradition and innovation. In: Constantin F (ed.) Proceedings of the Final Conference of the HempSys Project, 28 April. Bologna, Italy, 2006.

23. Rowell RM, Han JS and Rowell JS. Characterization and factors effecting fiber properties. In: Frollini E, Leão AL and Mattoso LHC (eds) Natural polymers and agrofiber based composites. Brazil: São Carlos, 2000, pp.115-134.

24. Gatti E, Di Virgilio N, Baronti S, and Bacci L. Development of Urtica dioica L. propagation methods for organic production of fiber. $16^{\text {th }}$ IFOAM Organic World Congress, June 16-20, Modena, Italy, 2008.

25. Bredemann G. Die große Brennessel Urtica dioica L. Forschung über ihren Anbau zur Fasergewinnung. Berlin: Akademieverlag, 1959.

26. Tamburini E, Gordillo Léon A, Perito P and Mastromei G. Characterization of bacterial pectinolytic strains involved in the water retting process. Environ Microbiol 2003; 5(9): 730-736.

27. Foulk A, Akin DE and Dodd RB. Influence of pectinolytic enzymes on retting effectiveness and resultant fiber properties. BioResources 2008; 3: 155-169.

28. Akin DE, Morrison III WH, Rigsby LL, Evans JD and Foulk JA. Influence of water presoak on enzyme-retting of flax. Ind Crops Prod 2003; 17(3): 149-159.

29. Adamsen APS, Akin DE and Rigsby LL. Chelating agents and enzyme retting of flax. Textile Res $J$ 2002; 72(4): 296-302. 
30. Evans JD, Akin DE and Foulk JA. Flax-retting by polygalacturonase-containing enzyme mixtures and effects on fibre properties. J Biotechnol 2002; 97(3): 223-231.

31. Nykter M, Kymäläinen H-R, Thomsen AB, Lilholt H, Koponen H, Sjöberg A-M, et al. Effects of thermal and enzymatic treatments and harvesting time on the microbial quality and chemical composition of fibre hemp (Cannabis sativa L). Biomass Bioenerg 2008; 32: 392-399.

32. Henriksson G, Akin DE, Rigsby LL, Patel N and Eriksson K-EL. Influence of chelating agents and mechanical pretreatment on enzymatic retting of flax. Textile Res $J$ 1997; 67: 829-836.

33. Foulk A, Akin DE and Dodd RB. Processing techniques for improving enzyme-retting of flax. Ind Crops Prod 2001; 13: 239-248.

34. Sharma HSS and Van Sumere C. The biology and processing of flax. Belfast: M. Publications, 1992.

35. Akin DE, Dodd RB, Perkins W, Henriksson G and Eriksson K-EL. Spray enzymatic retting: a new method for processing flax fibers. Textile Res $J$ 2000; 70(6): 486-494.

36. Van Soest PJ. Use of detergents in the analysis of fibrous feeds, II. A rapid method for the determination of fiber and lignin. J Assoc Off Anal Chem 1963; 46: 829-835.

37. Bodros E and Baley C. Study of the tensile properties of stinging nettle fibers (Urtica dioica). Mater Lett 2008; 62: 2143-2145.

38. Sharma HSS. Screening of polysaccharide-degrading enzymes for retting flax stem. Int Biodeterior 1987; 23: $181-186$.
39. Antonov V, Marek J, Bjelkova M, Smirous P and Fischer H. Easily available enzymes as natural retting agents. Biotechnol J 2007; 2: 342-346.

40. Akin DE, Rigsby LL and Perkins W. Quality properties of flax fibers retted with enzymes. Textile Res J 1999; 69(10): 747-753.

41. Jauneau A, Cabin-Flaman A, Verdus M-C, Ripoll C and Thellier M. Involvement of calcium in the inhibition of endopolygalacturonase activity in epidermis cell wall of Linum usitatissimum. Plant Physiol Biochem 1994; 32: 839-846.

42. Rihouey C, Jauneau A, Cabin-Faman A, Demarty M, Lefebvre $\mathrm{F}$ and Morvan $\mathrm{C}$. Calcium and acidic pectin distribution in flax cell walls: evidence for different kinds of linkages in the cell junction and middle lamella of the cortical parenchyma of flax hypocotyl. Plant Physiol Biochem 1995; 33: 497-508.

43. Sharma HSS. Chemical retting of flax using chelating compounds. Ann Appl Biol 1988; 113: 159-165.

44. Sharma HSS, Faughey G and Lyons G. Comparison of physical chemical and thermal characteristics of water-, dew-, and enzyme-retted flax fibers. J Appl Polymer Sci 1999; 74: 139-143.

45. Hobson RN, Hepworth DG and Bruce DM. Quality of fibre separated from unretted hemp stems by decortications. J Agric Eng Res 2001; 78(2): 153-158.

46. Hartl A and Vogl CR. Dry matter and fiber yields and the fiber characteristics of five nettle clones (Urtica dioica L.) organically grown in Austria for potential textile use. Am J Alternative Agr 2002; 17: 195-200.

47. Dujardin A. The retting of flax. Belfast: Carswell \& Son Ltd, 1948, p.181. 